\title{
HUBUNGAN LINGKUNGAN KELUARGA TERHADAP KARAKTER DISIPLIN DAN PRESTASI BELAJAR SISWA DI MI AL FIRDAUS LASEM SIDAYU GRESIK
}

\author{
Minahul Mubin \\ Universitas Islam Lamongan \\ e-mail: minahul.mubin2013@gmail.com
}

\begin{abstract}
This research is to find out 1. Relationship between Family Environment and Discipline Character and Student Learning Achievement at MI AL Firdaus Lasem Sidayu Gresik. 2. The relationship of learning discipline to the formation of character in students MI AL Firdaus Lasem Sidayu Gresik. This type of research is quantitative descriptive research. This study took the location at MI AL Firdaus Lasem Sidayu Gresik. Data collection techniques using a questionnaire technique. The data analysis technique used is multiple linear regression analysis, significance test of multiple linear regression ( $F$ test) and test the significance of the multiple linear regression coefficient ( $T$ test), In addition, the calculation of relative contributions and effective contributions is also carried out._The results of the regression analysis obtained the regression line equation: $Y=14, \overline{7} 82+0,432 X 1+0,392 X 2$. The equation shows that character building is influenced by the family environment and learning discipline. The conclusion of this research is 1. The family environment has a positive and significant effect on character building. Based on T test was obtained Tcount it > Ttabel, that is 6,342> 1,980 and the value of the probability of significance <0,05, that is 0,000. 2. Learning discipline has a positive and significant effect on character building. Based on $F$ test noted that $\mathrm{HO}$ rejected, becoause Fcount it > Ftabel, yaitu 49,342 > 3,072 and the value of the probability of significance $<0,05$, that is 0,000. 3. Family environment variables make effective contributions $25,7 \%$. Learning discipline variables make effective contributions $19,4 \%$, so the total effective contribution is $45,1 \%$, while $54,9 \%$ the rest is influenced by other variables not examined..
\end{abstract}

Keywords: Family Environment, Learning Discipline and Learning Achievement.

\section{A. Pendahuluan}

Sudah saatnya kita berfikir untuk meningkatkan belajar dan semangat belajar dalam rangkah menjawab tantangan zaman, seiring dengan itu persoalan muncul pada generasi muda yang harus menghadapi perkembangan teknologi yang semakin tidak dibendung atas perkembangan dan kebutuhannya, oleh karena membincang peningkatan kualitas belajar menjadi penting dan harus termasuk bagaimana membentuk karakter pada siswa. Karakter menjadi bagi perkembangan anak, karena dengan karakter anak mempunyai keyakinan dan kekuatan sikap dalam bertindak, bertutur sesuai dengan perkembangan dirinya. Menurut Pusat Bahasa Depdiknas dalam Amri dkk. (2011:3) 
"Karakter adalah bawaan, hati, jiwa, kepribadian, budi pekerti, perilaku, personalitas, sifat, tabiat, temperamen, watak". Remaja yang mempunyai karakter egois dan selalu ingin menang sendiri disebabkan hatinya tidak stabil dan ingin secara instan sehingga tidak bisa mengkontrol emosi. Pembentukan karakter dalam diri individu merupakan fungsi dari seluruh potensi individu manusia (kognitif, afektif, dan psikomotorik) dalam konteks interaksi sosial kultural (dalam lingkungan keluarga, sekolah dan masyarakat) yang berlangsung sepanjang hayat. Dari beberapa interaksi sosial tersebut, interaksi dalam lingkungan keluarga merupakan interaksi yang cukup penting dibandingkan dengan interaksi lainnya.

Pendidikan karakter bukan semata-mata tentang pengetahuan saja, namun terlebih tentang kepribadian dan perilaku siswa sehari-hari. Menurut Amri dkk. (2011:52) "Pendidikan karakter bertujuan untuk meningkatkan mutu pendidikan di sekolah yang mengarah pada pencapaian pembentukan karakter dan akhlak mulia peserta didik". Melalui pendidikan karakter diharapkan siswa mampu secara mandiri meningkatkan dan menggunakan pengetahuannya, mengkaji nilai-nilai karakter dan akhlak mulia sehingga terwujud dalam perilaku siswa sehari-hari dan sekaligus memiliki kepribadian yang baik sesuai norma-norma dan budaya pendidikan. Lingkungan keluarga sering dipandang sebagai lingkungan pendidikan karakter yang utama dalam masyarakat, karena dalam keluargalah manusia dilahirkan dan berkembang menjadi dewasa. Lingkungan menurut Sartain dalam Hasbullah (2001:32) "Yang dimaksud lingkungan (environment) meliputi kondisi dan alam dunia ini yang dengan cara-cara tertentu mempengaruhi tingkah laku kita, pertumbuhan, perkembangan atau life processes". Keluarga Menurut Hasbullah (2001:33) "Keluarga adalah sebagai kesatuan hidup bersama yang pertama dikenal oleh anak". Dari keterangan diatas dapat disimpulkan bahwa lingkungan keluarga menjadi bagian terpenting dalam membentuk karakter anak, membentuk kedewasan anak, serta membentengi anak dari gempuran kebebasan zaman.

Anak yang di didik dalam perilaku yang humanis, religius maka anak akan mengalami perkembangan yang relatif positif. Sedangkan anak yang dikembangkan dalam lingkungan keluarga yang kurang harmonis, orang tua yang bersikap keras pada anak, orang tua yang tidak memperhatikan nilai-nilai agama, maka perkembangan kepribadian anak cenderung mengalami kelainan dalam penyesuaian diri. Dengan adanya perbedaan tersebut akan mempengaruhi anak dalam meningkatkan kedisiplinan belajarnya.

Setiap orang pada dasarnya memiliki sikap disiplin pada dirinya, dan sikap disiplin ini tumbuh dikarenakan kepribadinya yang telah terbentuk karena lingkungannya, dan terbentuk karena perilaku lingkungan keluarganya pula sehingga disiplin ini diharapkan menjadi bekal budaya dalam perkembangan anak Menurut Djamarah (2002:12) "Disiplin adalah suatu tata tertib yang dapat mengatur tatanan 
kehidupan pribadi dan kelompok". Sikap disiplin timbul dari kehidupan pribadi seseorang karena ada dorongan untuk mentaati tata tertib yang ada. Dalam belajar disiplin sangat diperlukan karena dapat melahirkan semangat menghargai waktu, orangorang yang berhasil dalam belajar disebabkan adanya dorongan dari diri sendiri. Dalam sekolah sering kita jumpai kegiatan yang berhubungan dengan disiplin, akan tetapi masih banyak siswa yang melanggar tata tertib di sekolah. Seorang siswa dalam mengikuti kegiatan belajar di sekolah tidak lepas dari tata tertib yang ada di sekolah tersebut, dan siswa dituntut untuk dapat berperilaku sesuai dengan aturan dan tata tertib yang berlaku di sekolahnya.

Tujuan disiplin adalah "(1) Memberi dukungan bagi terciptanya perilaku yang tidak menyimpang, (2) Mendorong siswa melakukan yang baik dan benar, 3) Membantu siswa memahami dan menyesuaikan diri dengan tuntutan lingkungannya dan menjauhi melakukan hal-hal yang dilarang oleh sekolah, dan (4) Siswa belajar hidup dengan kebiasaankebiasaan yang baik dan bermanfaat baginya serta lingkungannya".

Dengan demikian disiplin mampu mengurangi perilaku perilaku yang tidak baik, dengan membiasakan memahami melaksanakan peraturan sekolah secara otomatis membiasakan budaya merubah perilaku. Dengan disiplin belajar terdapat kecenderungan bagi siswa agar terbiasa dengan aktivitas belajar yang dilakukan secara teratur yang mana belajar merupakan kegiatan yang mendasar atau kegiatan pokok yang dilakukan dengan kesadaran hati sehingga tidak perlu adanya pikiran dari orang lain. Kedisiplinan yang ditanamkan orang tua sejak dini, menjadikan anak akan terbiasa melakukan pekerjaan tanpa adanya beban dan paksaan dari orang lain.

Berdasarkan uraian di atas, maka dapat dirumuskan beberapa masalah yaitu adakah hubungan lingkungan keluarga terhadap pembentukan karakter pada siswa Di Mi Al Firdaus Lasem Sidayu Gresik, adakah pengaruh kedisiplinan belajar terhadap pembentukan karakter pada siswa di MI Al Firdaus Lasem Sidayu Gresik.

Penelitian ini diharapkan dapat memberikan manfaat: (1) Menambah konsep atas teori tentang hubungan lingkungan keluarga dan kedisiplinan belajar terhadap pembentukan karakter pada siswa. (2) Menambah wawasan dan pengetahuan tentang kedisiplinan belajar. (3) Bagi semua orang tua untuk menciptakan lingkungan keluarga yang lebih harmonis, dan menumbuhkan kesadaran bagi orang tua dalam memperhatikan perilaku anak dalam membentuk karakter yang baik di lingkungan keluarga. (4) Sebagai masukan bagi siswa terhadap pentingnya penerapan kedisiplinan belajar dalam diri siswa. (5) Sebagai referensi untuk penelitian berikutnya yang sejenis.

Pembentukan karakter pada anak berawal dari usia dini dengan ditanamkan kebiasaan - kebiasaan yang positif yang diajarkan oleh orang tua, di sekolah harus membangun karakter siswa yang positif sehingga tidak hanya mencetak generasi yang berhasil dalam bidang kognitif tapi juga afektif (moral). Menurut Amri dkk. (2011:94) 
"Pembangunan bangsa dimulai dari pembangunan karakter pelajar dari usia dini sehingga untuk memajukan bangsa ini diperlukan kurikulum yang tidak hanya mencetak siswa berprestasi dalam nilai namun juga yang berkarakter berani, positif namun tetap sopan".

Peran aktif orang tua terhadap pembentukan karakter anak sangat diperlukan, peran dalam menciptakan lingkungan rumah sebagai lingkungan sosial yang pertama dialami oleh anak. Melalui pengamatannya terhadap tingkah laku orang tua secara berulang-ulang, anak ingin meniru kemudian menjadi ciri kebiasaan atau kepribadiannya. Di sekolah yang berperan penting dalam pembentukan karakter adalah guru, guru harus dapat menjadikan dirinya sebagai contoh berkarakter yang baik. Dengan mengajarkan perilaku yang baik misalnya mengucapkan terima kasih, meminta maaf, tidak memotong siswa yang mengutarakan pendapat, menghormati siswa merupakan strategi yang baik dalam membentuk karakter siswa.

Dalam pembentukan karakter terdapat faktor (http://duniabaca.com/teorikepribadian) “ Ada dua faktor yaitu faktor keturunan dan faktor lingkungan”. Lingkungan keluarga berasal dari kata lingkungan dan keluarga. Menurut Sartain dalam Purwanto (2003:28)" Lingkungan (environment) ialah meliputi semua kondisi-kondisi dalam dunia ini yang dalam cara-cara tertentu mempengaruhi tingkah laku kita, pertumbuhan, perkembangan atau life processes". Menurut Khairuddin (1997:3) "Keluarga adalah kelompok sosial kecil yang umumnya terdiri dari ayah, ibu, dan anak yang mempunyai hubungan sosial di antara anggota relatif tetap dan didasarkan atas ikatan darah, perkawinan dan adopsi”. Jadi Lingkungan Keluarga merupakan kondisi dalam dunia ini yang dalam cara-cara tertentu mempengaruhi tingkah laku kita serta seluruh kondisi yang ada di dalam kelompok sosial kecil yang terdiri atas ayah, ibu dan anak yang mempunyai hubungan sosial karena adanya ikatan darah, perkawinan dan adopsi.

Anggota keluarga ditandai dengan hidup bersama di bawah satu atap dan merupakan susunan satu rumah tangga, yang merupakan kesatuan dari orang-orang yang berinteraksi dan berkomunikasi yang menciptakan peranan-peranan sosial bagi ayah, ibu, dan anak. Menurut Khairuddin (1997:48) "Keluarga mempunyai fungsifungsi pokok yang sulit dirubah dan digantikan oleh orang lain, yaitu: Fungsi biologik, fungsi afeksi,dan fungsi sosialisasi". Kedisiplinan berasal dari kata sifat yaitu disiplin. Menurut Arikunto (2001:114) "Disiplin adalah kepatuhan seseorang dalam mengikuti peraturan atau tata tertib didorong oleh adanya kesadaran yang ada pada kata hatinya". Menurut Poerwadarminto (2003:254) "Disiplin adalah suatu latihan batin dan watak dengan maksud supaya segala perbuatan selalu mentaati tata tertib". Dari kedua pengertian di atas maka dapat disimpulkan bahwa disiplin adalah suatu bentuk kepatuhan seseorang dalam mengikuti tata tertib atau peraturan karena didorong oleh 
kesadaran yang ada pada kata hatinya, kesadaran ini diperoleh karena melalui latihanlatihan. Menurut Slameto (2003:2) "Belajar ialah suatu proses usaha yang dilakukan seseorang untuk memperoleh suatu perubahan tingkah laku yang baru secara keseluruhan, sebagai pengalamannya sendiri dalam interaksi dengan lingkungannya".

Dengan demikian pengertian disiplin belajar adalah suatu bentuk usaha dan kepatuhan siswa yang dilandasi oleh kesadaran pribadi terhadap peraturanperaturan yang dibuat oleh diri sendiri atau pihak lain dalam usahanya untuk memperoleh perubahan baik pengetahuan, ketrampilan dan sikap sebagai hasil dari latihan-latihan yang dilakukan.

Dengan demikian disiplin bisa mendorong siswa agar tidak melakukan perilaku yang menyimpang misalnya mencuri barang orang lain, mudah menyesuaikan diri dengan lingkungan, dan tidak mudah terpengaruh dengan perbuatan yang melanggar tata tertib sekolah. Dengan adanya disiplin semua kegiatan dan perbuatan baik dengan sendirinya akan mengalir dengan sendirinya.

Hipotesis yang diajukan dalam penelitian ini adalah (1) Lingkungan keluarga berpengaruh positif terhadap pembentukan karakter pada siswa di MI Al Firdaus Lasem Sidayu Gresik. (2) Kedisiplinan belajar berpengaruh positif terhadap pembentukan karakter pada siswa di MI Al Firdaus Lasem Sidayu Gresik . (3) Lingkungan keluarga dan kedisiplinan belajar berpengaruh positif terhadap pembentukan karakter pada siswa di MI Al Firdaus Lasem Sidayu Gresik.

\section{B. Metode}

Jenis penelitian ini adalah penelitian deskriptif kuantitatif karena menggunakan data yang berbentuk angka atau data kualitatif yang diangkakan. Penelitian ini mengambil lokasi di MI Al Firdaus Lasem Sidayu Gresik. Populasi yang digunakan dalam penelitian ini adalah siswa di MI Al Firdaus Lasem Sidayu Gresik dengan menggunakan teknik proportional random sampling. Teknik pengumpulan data menggunakan teknik angket dan dokumentasi. Teknik analisis data yang digunakan adalah analisis regresi linear ganda, uji keberartian regresi linear ganda (uji F) dan uji keberartian koefisien regresi linier ganda (uji t), selain itu dilakukan pula perhitungan sumbangan relatif dan sumbangan efektif.

\section{Hasil dan Pembahasan}

1. Uji Validitas dan Reliabilitas

Tabel. 1. Hasil uji validitas angket lingkungan keluarga

\begin{tabular}{|l|l|l|l|}
\hline No Item & rxy & $\mathrm{r}(0,05 ; 20)$ & Kesimpulan \\
\hline 1. & 0,556 & 0,444 & Valid \\
\hline 2. & 0,562 & 0,444 & Valid \\
\hline 3. & 0,536 & 0,444 & Valid \\
\hline
\end{tabular}




\begin{tabular}{|l|l|l|l|}
\hline 4. & 0,260 & 0,444 & Tidak valid \\
\hline 5. & 0,583 & 0,444 & Valid \\
\hline 6. & 0,599 & 0,444 & Valid \\
\hline 7. & 0,615 & 0,444 & Valid \\
\hline 8. & 0,514 & 0,444 & Valid \\
\hline 9. & 0,176 & 0,444 & Tidak valid \\
\hline 10. & 0,531 & 0,444 & Valid \\
\hline 11. & 0,492 & 0,444 & Valid \\
\hline 12. & 0,502 & 0,444 & Valid \\
\hline 13. & 0,502 & 0,444 & Valid \\
\hline 14. & 0,524 & 0,444 & Valid \\
\hline 15. & 0,533 & 0,444 & Valid \\
\hline 16. & 0,504 & 0,444 & Valid \\
\hline 17. & 0,476 & 0,444 & Valid \\
\hline 18. & 0,495 & 0,444 & Valid \\
\hline 19. & 0,560 & 0,444 & Valid \\
\hline 20. & 0,499 & 0,444 & Valid \\
\hline
\end{tabular}

Tabel. 2 Hasil uji validitas angket kedisiplinan belajar

\begin{tabular}{|l|l|l|l|}
\hline No Item & rxy & $\mathrm{r}(0,05 ; 20)$ & Kesimpulan \\
\hline 1. & 0,491 & 0,444 & Valid \\
\hline 2. & 0,598 & 0,444 & Valid \\
\hline 3. & 0,525 & 0,444 & Valid \\
\hline 4. & 0,554 & 0,444 & Valid \\
\hline 5. & 0,684 & 0,444 & Valid \\
\hline 6. & 0,184 & 0,444 & Tidak Valid \\
\hline 7. & 0,623 & 0,444 & Valid \\
\hline 8. & 0,007 & 0,444 & Tidak Valid \\
\hline 9. & 0,607 & 0,444 & Valid \\
\hline 10. & 0,473 & 0,444 & Valid \\
\hline 11. & 0,516 & 0,444 & Valid \\
\hline 12. & 0,566 & 0,444 & Valid \\
\hline 13. & 0,590 & 0,444 & Valid \\
\hline 14. & 0,485 & 0,444 & Valid \\
\hline 15. & 0,607 & 0,444 & Valid \\
\hline 16. & 0,485 & 0,444 & Valid \\
\hline 17. & 0,563 & 0,444 & Valid \\
\hline
\end{tabular}




\begin{tabular}{|l|l|l|l|}
\hline 18. & 0,556 & 0,444 & Valid \\
\hline 19. & 0,150 & 0,444 & Tidak Valid \\
\hline 20. & 0,519 & 0,444 & Valid \\
\hline
\end{tabular}

Tabel. 3 Hasil uji validitas angket pembentukan karakter

\begin{tabular}{|l|l|l|l|}
\hline No Item & rxy & $\mathrm{r}(0,05 ; 20)$ & Kesimpulan \\
\hline 1. & 0,126 & 0,444 & Tidak Valid \\
\hline 2. & 0,507 & 0,444 & Valid \\
\hline 3. & 0,587 & 0,444 & Valid \\
\hline 4. & 0,508 & 0,444 & Valid \\
\hline 5. & 0,601 & 0,444 & Valid \\
\hline 6. & 0,551 & 0,444 & Valid \\
\hline 7. & 0,472 & 0,444 & Valid \\
\hline 8. & 0,515 & 0,444 & Valid \\
\hline 9. & 0,647 & 0,444 & Valid \\
\hline 10. & 0,534 & 0,444 & Valid \\
\hline 11. & 0,560 & 0,444 & Valid \\
\hline 12. & 0,523 & 0,444 & Valid \\
\hline 13. & 0,226 & 0,444 & Tidak Valid \\
\hline 14. & 0,583 & 0,444 & Valid \\
\hline 15. & 0,546 & 0,444 & Valid \\
\hline 16. & 0,526 & 0,444 & Valid \\
\hline 17. & 0,574 & 0,444 & Valid \\
\hline 18. & 0,509 & 0,444 & Valid \\
\hline 19. & 0,490 & 0,444 & Tidak Valid \\
\hline 20. & 0,530 & 0,444 & Valid \\
\hline & & & \\
\hline
\end{tabular}

Berdasarkan table 4.1, 4.2, dan 4.3 diketahui bahwa lingkungan keluarga memiliki 18 pernyataan valid, kedisiplinan belajar memiliki 17 pernyataan valid dan pembentukan karakter memiliki 18 pernyataan valid.

Uji reliabilitas angket dilakukan menggunakan menggunakan perhitungan SPSS for windows 12.0. Hasil uji reliabilitas diperoleh nilai koefisien reliabilitas angket lingkungan keluarga sebesar 0,845, angket kedisiplinan belajar sebesar 0,854 dan angket pembentukan karakter sebesar 0,851. Berdasarkan nilai koefisien reliabilitas tersebut dapat dikatakan bahwa angket lingkungan keluarga, kedisiplinan belajar dan pembentukan karakter memiliki reliabilitas yang tinggi. Sehingga sangat layak untuk digunakan sebagai instrumen penelitian. 
Dari hasil analisis dan perhitungan untuk nilai tertinggi, nilai terendah, skor ratarata, median, modus, standar deviasi, dan varian dapat dilihat pada tabel di bawah ini.

Tabel.4 Ringkasan Diskripsi Data lingkungan keluarga, kedisiplinan belajar, dan pembentukan karakter

\begin{tabular}{|l|c|c|c|}
\hline & $\begin{array}{l}\text { Lingkungan } \\
\text { Keluarga }\end{array}$ & $\begin{array}{l}\text { Kedisiplinan } \\
\text { Belajar }\end{array}$ & $\begin{array}{l}\text { Pembentukan } \\
\text { Karakter }\end{array}$ \\
\hline N Valid & 123 & 123 & 123 \\
Missing & 0 & 0 & 0 \\
\hline Mean & 54.30 & 47.70 & 56.93 \\
\hline Median & 54.00 & 48.00 & 57.00 \\
\hline Mode & $53 a$ & 48 & 57 \\
\hline Std. Deviation & 5.551 & 5.089 & 5.310 \\
\hline Variance & 30.819 & 25.901 & 28.192 \\
\hline Range & 23 & 23 & 22 \\
\hline Minimum & 43 & 36 & 45 \\
\hline Maximum & 66 & 59 & 67 \\
\hline Sum & 6679 & 5867 & 7003 \\
\hline
\end{tabular}

2. Uji Normalitas

Tabel. 5 Hasil Uji Normalitas

\begin{tabular}{|l|c|c|c|l|l|}
\hline Variabel & $\mathrm{n}$ & \multicolumn{2}{|c|}{ Harga L0 } & sig. & Kesimpulan \\
\cline { 2 - 5 } & & $\begin{array}{c}\text { Lhitun } \\
\mathrm{g}\end{array}$ & $\begin{array}{c}\text { L0,05, } \\
123\end{array}$ & & \\
\hline $\begin{array}{l}\text { Lingkungan } \\
\text { keluarga }\end{array}$ & 123 & 0,052 & 0,080 & 0.200 & Normal \\
\hline $\begin{array}{l}\text { Kedisiplinan } \\
\text { belajar }\end{array}$ & 123 & 0,052 & 0,080 & 0.200 & Normal \\
\hline $\begin{array}{l}\text { Pembentukan } \\
\text { karakter }\end{array}$ & 123 & 0,051 & 0,080 & 0.200 & Normal \\
\hline
\end{tabular}

Dari tabel di atas diketahui harga Lhitung masing-masing variabel lebih kecil dari Ltabel dan nilai probabilitas signifikansi $>0,05$, sehingga dapat disimpulkan bahwa data sampel dari masing-masing variabel berasal dari populasi yang berdistribusi normal.

3. Uji linearitas

Tabel. 6. Ringkasan Uji Linearitas

\begin{tabular}{|l|c|c|c|c|}
\hline Variabel & \multicolumn{2}{|c|}{ Harga F } & \multirow{2}{*}{ sig. } & Kesimpulan \\
\cline { 2 - 3 } yang diukur & Fhitung & Ftabel & & \\
\hline
\end{tabular}




\begin{tabular}{|l|c|c|c|c|}
\hline X1Y & 1,304 & $\begin{array}{c}\text { F0,05;22,99 }= \\
1,651\end{array}$ & 0,188 & Linear \\
\hline X2Y & 0,918 & $\begin{array}{c}\text { F0,05;22,99 }= \\
1,651\end{array}$ & 0,572 & Linear \\
& & & \\
\hline
\end{tabular}

Dari Tabel 4.9 diketahui harga Fhitung masing-masing variabel yang diukur lebih kecil dari Ftabel dan nilai probabilitas signifikansi $>0,05$, sehingga dapat disimpulkan bahwa hubungan antara masing-masing variabel bebas dengan variabel terikat berbentuk linear.

4. Analisis Regresi Linear Berganda

Tabel 7. Ringkasan hasil analisis regresi linear ganda

\begin{tabular}{|l|l|l|l|}
\hline Variabel & Koefisien Regresi & $\mathrm{t}$ & $\mathrm{sig}$ \\
\hline Konstanta & 14,782 & 3,469 & 0,001 \\
\hline $\begin{array}{l}\text { Lingkungan } \\
\text { keluarga }\end{array}$ & 0,432 & 6,342 & 0,000 \\
\hline $\begin{array}{l}\text { Kedisiplinan } \\
\text { belajar }\end{array}$ & 0,392 & 5,279 & 0,000 \\
\hline $\begin{array}{l}\text { F hitung }=49,342 \\
\text { R2 }=0,451\end{array}$ & & \\
\hline
\end{tabular}

Berdasarkan Tabel 4.10. diperoleh persamaan regresi linear ganda sebagai berikut $: Y=14,782+0,432 X 1+0,392 X 2$. Dari persamaan tersebut dapat disimpulkan bahwa pembentukan karakter siswa kelas VIII SMP Muhammadiyah 5 surakarta dipengaruhi oleh lingkungan keluarga dan kedisiplinan belajar.

\section{Pengujian Hipotesis}

Hasil pengujian hipotesis pertama diperoleh uji t sebesar 6,342 dan nilai signifikansi 0,000. Hal ini menunjukkan bahwa thitung $>$ ttabel, yaitu 6,342 > 1,980 dan nilai probabilitas signifikansi $<0,05$, yaitu 0,000 . Sehingga dapat disimpulkan bahwa Lingkungan keluarga berpengaruh positif dan signifikan terhadap pembentukan karakter.

Hasil pengujian hipotesis kedua diperoleh uji $t$ sebesar 5,279 dan nilai signifikansinya sebesar 0,000. Hal ini menunjukkan bahwa thitung > ttabel, yaitu 5,279 $>1,980$ dan nilai probabilitas signifikansi $<0,05$, yaitu 0,000 . Sehingga kedisiplinan belajar berpengaruh positif dan signifikan terhadap pembentukan karakter.

Hasil pengujian hipotesis ketiga diperoleh nilai $\mathrm{F}$ hitung sebesar 49,342 dengan signifikansi 0,000. Hal ini menunjukkan bahwa Fhitung > Ftabel, yaitu 49,342 > 3,072 dan nilai probabilitas signifikansi $<0,05$, yaitu 0,000 . Sehingga lingkungan keluarga 
dan kedisiplinan belajar secara bersama-sama berpengaruh positif dan signifikan terhadap pembentukan karakter.

6. Koefisien Determinasi

Berdasarkan analisis data menggunakan alat bantu program SPSS 12.0, diketahui bahwa nilai koefisien determinasi (R2) adalah sebesar 0,451. Arti dari koefisien ini adalah bahwa pengaruh yang diberikan oleh kombinasi variabel lingkungan keluarga dan kedisiplinan belajar terhadap pembentukan karakter adalah sebesar 45,1\%, sedangkan sisanya 54,9\% dipengaruhi oleh variabel lain.

7. Sumbangan Relatif dan Sumbangan Efektif

Dari hasil perhitungan diketahui bahwa variabel lingkungan keluarga memberikan sumbangan relatif sebesar 56,9\% dan sumbangan efektif $25,7 \%$. Variabel kedisiplinan belajar memberikan sumbangan relatif sebesar 43,1\% dan sumbangan efektif 19,4\%. Berdasarkan besarnya sumbangan relatif dan efektif nampak bahwa variabel lingkungan keluarga memiliki pengaruh yang lebih banyak terhadap pembentukan karakter dibandingkan variabel kedisiplinan belajar.

Berdasarkan hasil analisis data menunjukkan bahwa secara individual dan secara bersama-sama lingkungan keluarga dan kedisiplinan belajar berpengaruh positif terhadap pembentukan karakter. Hal ini dapat dilihat dari nilai koefisien regresi dari masing-masing bebas bernilai positif, seperti yang terlihat pada persamaan regresi linear ganda sebagai berikut: $\mathrm{Y}=14,782+0,432 \mathrm{X} 1+0,392 \mathrm{X} 2$. Dari hasil analisis data diperoleh nilai koefisien determinasi (R2) sebesar 0,451 yang menunjukkan bahwa kombinasi variabel lingkungan keluarga dan kedisiplinan belajar berpengaruh terhadap pembentukan karakter sebesar 45,1\%, sedangkan 54,9\% sisanya dipengaruhi oleh variabel lain yang tidak diteliti.

Hasil pengujian hipotesis pertama diperoleh thitung $>$ ttabel, yaitu 6,342 > 1,980 dan nilai probabilitas signifikansi $<0,05$, yaitu 0,000. Dengan sumbangan efektif sebesar $25,7 \%$ sedangkan sumbangan relatifnya sebesar 56,9\%. Sehingga dapat disimpulkan bahwa Lingkungan keluarga berpengaruh positif dan signifikan terhadap pembentukan karakter, Berdasarkan kesimpulan tersebut dapat dikatakan bahwa semakin baik kualitas lingkungan keluarga akan semakin baik pembentukan karakter siswa. Sebaliknya semakin rendah kualitas lingkungan keluarga, maka semakin rendah pembentukan karakter siswa.

Hasil pengujian hipotesis kedua diperoleh thitung $>$ ttabel, yaitu 5,279 > 1,980 dan nilai probabilitas signifikansi $<0,05$, yaitu 0,000. Dengan sumbangan efektif sebesar $19,4 \%$ sedangkan sumbangan relatifnya sebesar 43,1\%. sehingga dapat disimpulkan bahwa variabel kedisiplinan belajar berpengaruh positif terhadap pembentukan karakter. Berdasarkan kesimpulan tersebut dapat dikatakan bahwa semakin tinggi kedisiplinan belajar akan semakin tinggi pembentukan karakter siswa, 
demikian pula sebaliknya semakin rendah kedisiplinan belajar akan semakin rendah pembentukan karakter siswa.

Hasil pengujian hipotesis ketiga diperoleh nilai $F$ hitung sebesar 49,342 dengan signifikansi 0,000. Hal ini menunjukkan bahwa Fhitung > Ftabel, yaitu 49,342 > 3,072 dan nilai probabilitas signifikansi $<0,05$, yaitu 0,000. Sehingga lingkungan keluarga dan kedisiplinan belajar secara bersama-sama berpengaruh positif dan signifikan terhadap pembentukan karakter. Berdasarkan kesimpulan tersebut dapat dikatakan bahwa kecenderungan peningkatan kombinasi variabel lingkungan keluarga dan kedisiplinan belajar akan diikuti peningkatan pembentukan karakter siswa. Sebaliknya kecenderungan penurunan kombinasi variabel lingkungan keluarga dan kedisiplinan belajar akan diikuti penurunan pembentukan karakter siswa.

Dari perhitungan diketahui bahwa variabel lingkungan keluarga memberikan sumbangan efektif $25,7 \%$. Variabel kedisiplinan belajar memberikan sumbangan efektif $19,4 \%$. Berdasarkan besarnya sumbangan efektif nampak bahwa variabel lingkungan keluarga memiliki pengaruh yang lebih dominan terhadap pembentukan karakter dibandingkan variabel kedisiplinan belajar.

\section{Simpulan}

Hasil uji hipotesis pertama dan kedua diketahui bahwa koefisien arah regresi dari variabel lingkungan keluarga dan kedisiplinan belajar mempunyai nilai positif. Dengan demikian dapat dikatakan bahwa semakin baik lingkungan keluarga dan kedisiplinan belajar akan semakin baik juga pembentukan karakter siswa, sebaliknya semakin rendah lingkungan keluarga dan kedisiplinan belajar akan semakin rendah pula pembentukan karakternya.

Berdasarkan uji keberartian regresi linier berganda atau uji $\mathrm{F}$ diketahui lingkungan keluarga dan kedisiplinan belajar secara bersama-sama berpengaruh positif sehingga keduanya bernilai positif. Berdasarkan hal tersebut dapat dikatakan bahwa kecenderungan peningkatan kombinasi lingkungan keluarga dan kedisiplinan belajar akan diikuti peningkatan pembentukan karakter siswa, sebaliknya kecenderungan penurunan kombinasi variabel lingkungan keluarga dan kedisiplinan belajar akan diikuti penurunan pembentukan karakter siswa.

Sedangkan koefisien determinasi lingkungan keluarga memiliki nilai yang lebih tinggi dari kedisiplinan belajar sehingga variabel lingkungan keluarga lebih berpengaruh terhadap pembentukan karakter siswa. Sedangkan sumbangan efektif untuk variabel lingkungan keluarga memiliki nilai yang lebih tinggi dari variabel kedisiplinan belajar sehingga dapat disimpulkan variabel lingkungan keluarga lebih dominan dari variabel kedisiplinan belajar sedangkan sisanya dipengaruhi oleh variabel lain. 


\section{Daftar Rujukan}

Amri, Sofan,dkk. 2011. Implementasi Pendidikan Karakter Dalam Pembelajaran. Jakarta : Prestasi Pustaka.

Arikunto, Suharsimi. 2001. Manajemen Penelitian. Jakarta: Rineka Cipta.

Djamarah, Syaiful Bahri. 2002. Rahasia Sukses Belajar. Jakarta: Rineka Cipta.

Hasbullah. 2001. Dasar-Dasar Ilmu Pendidikan. Jakarta: PT Raja Grafindo Persada.

Khairuddin. 1997. Sosiologi Keluarga. Yogyakarta : Liberty. Pembentukan karakter (http://www.pakboer.com/proses-pembentukankarakter-pada-anak) diakses tanggal 22 maret 2012

Pembentukan Kepribadian : (http://duniabaca.com/teori-kepribadian-sertafaktor-faktor pembentuk-kepribadian.html) diakses tanggal 17 Juni 2012 .

Purwanto, Ngalim.2003. Psikologi Pendidikan. Bandung: Rosdakarya.

Slameto. 2003, Belajar dan Faktor-Faktor yang Mempengaruhinya. Jakarta : Rineka Cipta. 